\title{
Alabalık (Oncorhynchus mykiss) ve Atıklarından Balık Sosu Üretimi ve Kalite Özelliklerinin Belirlenmesi
}

\author{
Hasan Basri Ormancı ${ }^{1}$ İbrahim Ender Künili ${ }^{2 *}$ Fatma Arık Çolakoğlu ${ }^{1}$
}

\author{
${ }^{1}$ Çanakkale Onsekiz Mart Üniversitesi, Çanakkale Uygulamalı Bilimler Yüksek Okulu, 17020, Çanakkale \\ ${ }^{2}$ Çanakkale Onsekiz Mart Üniversitesi, Deniz Bilimleri ve Teknolojisi Fakültesi, 17020, Çanakkale \\ *Sorumlu yazar: enderkunili@yahoo.com
}

Geliş Tarihi: 06.09.2018

Kabul Tarihi: 03.12.2018

\section{$\ddot{\mathbf{O z}}$}

$\mathrm{Bu}$ araştırmada, önemli bir kültür balığı olan alabalığın balık sosu olarak değerlendirilmesi ve ekonomik bir ürün elde edilerek ürün yelpazesinin geliştirilmesi amaçlanmıştır. Çalışmada, Çanakkale Bayramiç'teki bir yetiştiricilik çiftliğinden temin edilen alabalıklar kullanılmış, farklı oranlarda baharat ve tuz ile harmanlanan sos hamurları iki ay boyunca $37^{\circ} \mathrm{C}$ 'de inkübasyona tabi tutularak fermente edilmiștir. Fermantasyon sonrasında üretilen sosların kalite özellikleri, duyusal, fiziko-kimyasal ve mikrobiyolojik analizleri yapılarak, belirlenmiştir. Elde edilen bulgularda, sosların beğeni ile tüketime uygun ürünler olduğu ve alabalık atıklarından üretilen sosların kalite açısından bütün balıklardan üretilen soslarla benzer özelliklere sahip olduğu belirlenmiştir. Sonuç olarak, balıkların besin olarak tüketilen kas kısımlarının yanı sıra, atık olarak nitelendirilen kısımlarının da sos olarak değerlendirilebileceği tespit edilmiştir.

Anahtar Kelimeler: Alabalık, Balık atıkları, Sos üretimi, Kalite özellikleri

\section{Fish Sauce Production and Determination of Quality Characteristics from Rainbow Trout and its Wastes Abstract}

In this study, it was aimed to evaluation of rainbow trout, which is an important culture fish species, as fish sauce and obtain new food stuff to improve product range. For this purpose, rainbow trouts were provided from a fish culture facility found in Bayramiç, Çanakkale. Fish samples minced and mixed with different ratio of salt and species. After bottling of fish minces, they were subjected to incubation for 2 months at $37^{\circ} \mathrm{C}$. After incubation, the quality characteristics of products were determined with physical, chemical, microbiological and sensorial analysis. According to the results, fish sauces obtained from this study were determined as suitable for consume. Fish sauce groups, whole and waste, were found to be similar sensorial properties and mostly liked over the average points by consumers. In conclusion, it was determined that rainbow trout can be evaluated as fish sauces, along with this, wastes of this fish also can be turned into valuable food products.

Keywords: Rainbow trout, Fish waste, Fish sauce production, Quality characteristics

\section{Giriş}

Su ürünleri ve özellikle balık, ülkemizde hayvansal protein açığını kapatabilecek potansiyele sahip, önemli bir besin kaynă̆ıdır. Beslenme için gereken tüm besin öğelerini bulundurması bu etleri değerli bir gıda maddesi yapmakta, ancak yapısal özellikleri nedeniyle su ürünleri etleri oldukça kolay bozulabilmektedir. $\mathrm{Bu}$ nedenle genellikle teknolojik işlemlere tabi tutularak, farklı tat ve aromada dayanıklı ürünler haline getirilmektedir. Su ürünleri işlemeciliği sırasında, insan gıdası olarak değer taşımayan ve atık olarak nitelendirilen bazı kısımlar da ortaya çıkmaktadır. Baş, kılçık, iç organlar, deri ve gonadlar gibi kısımlardan oluşan bu kısımlar, genellikle üretim sonrası işletmelerde bertaraf edilmektedir. Aslında bu atıklar, besin olarak kullanılan kas kısımları gibi, değerli protein, lipit, vitamin ve mineralleri içermektedir (Gildberg, 2001; García ve ark., 2005; Gao ve ark., 2006). Bunların değerlendirilmesi ve fonksiyonel ürünler olarak hazırlanması hem ülke ekonomisi hem de çevre sağlığı açısından son derece önemlidir (Alasalvar ve ark., 2002; Shahidi, 2002).

Balık sosu, berrak kırmızıdan kahverengiye dönen kehribar renginde, güçlü koku ve aroması olan sıvı bir üründür. Güçlü aroma zenginliğinden dolayı yemeklere ilave edilebilmekte veya sofrada et, deniz ürünleri, kızartma vb.nin içine batırıldığı sos olarak da kullanılabilmektedir (ICMSF, 1986; Lopetcharat ve ark., 2001). Bu ürün, başta Avrupa ülkeleri olmak üzere dünyanın birçok ülkesinde beğeniyle tüketilmekte ve bu nedenle de dünyada tüm su ürünleri istihsalinin yaklaşık \%1'i balık sosu 
üretiminde kullanılmaktadır (Gildberg ve ark., 2007). Ülkemizde balık soslarının ticari üretim ve tüketimlerine ait bir bilgi bulunmamaktadır. Asya ülkelerinde yıllık 250.000 ton civarında balık sosunun üretilerek hem iç tüketime, hem de ihracata verildiği (Stefansson ve Steingrimsdottir, 1990) düşünülürse, ülkemizde de bu ürünün bir potansiyelinin olabileceği açıktır.

$\mathrm{Bu}$ ürün grubunu ülkemizde daha yakından tanımak ve tanıtmak amacıyla yapılan bu çalışmada, alabalık ve atıklarından balık sosu üretimi gerçekleștirilmiş ve kalite özellikleri duyusal, fizikokimyasal ve mikrobiyolojik analizlerle incelenmiştir. Çalışma sonucunda üretilen ürünle, su ürünleri sektöründe katma değerin artırılması ve değerlendirilemeyen atıkların geri kazanımına 1şı tutulacak, böylece hem ülke ekonomisine hem de atıklarla oluşan çevre kirliliğinin önlenmesine katkı verilmiş olunacaktır.

\section{Materyal ve Yöntem \\ Materyal}

Araştırmada materyal olarak gökkuşağı alabalığı (Oncorhyncus mykiss) kullanılmıştır. Örnekler, Aralık 2015'te Çanakkale Bayramiç/Ayazma'daki bir yetiştiricilik çiftliğinden temin edilmiş ve soğutulmuş olarak üç saat içinde Deniz Bilimleri ve Teknolojisi Fakültesi, laboratuvarlarına getirilmiştir. Araştırmada toplam $75 \mathrm{~kg}$ taze alabalık örneği kullanılmıştır.

Sos hazırlığında kullanılan tuz ve baharatlar, \% 99,5 saflıkta ticari deniz tuzu (Uyar Tuz San. ve Tic. A.Ş.), şeker (Torku-Konya Şeker San. ve Tic. A.Ş.) baharat olarak ise kırmızı toz biber, karabiber, biberiye ve karanfil (Bağdat Baharatları Gıda San. ve Tic. Ltd. Şti.) tercih edilmiştir.

\section{Yöntem}

Sos Üretimi

Balık örnekleri, "bütün balık" ve "atık" olmak üzere iki gruba ayrılmıştır. Örnek grupların hazırlığında "bütün balık" grubunda, balık örnekleri ayıklanıp, temizlendikten sonra kıyma haline getirilmiştir. Atık grubu ise balıkların temizlenmesi sonrası elde edilen; baş, iç organ, kemik, kılçık ve yüzgeçler (fileto alımı sonrası oluşan atık) kıyma haline getirilmiştir. Her iki grubun kıyma haline getirilmesinden sonra, $\% 20$ tuz, $\% 4$ şeker, $\% 1$ kırmızı biber, $\% 0,5$ karabiber ve $\% 0,2$ karanfil ilave edilerek, harç iyice karıştııılmıștır (Şekil 1). Baharatların ilavesinden sonra sos hamurları 500 ila 2000 ml'lik cam kavanozlara alınmış, ağızları iyice kapatıldıktan sonra $37^{\circ} \mathrm{C}$ 'de iki ay boyunca karanlıkta inkübasyona tabi tutulmuştur. İnkübasyon sonunda örnekler ilk olarak kaba filtreden (tülbent), sonrasında ise ince filtreden (Whatman No:1) süzülerek analizlere alınmıştır.

Duyusal Analizler

Duyusal analizler iki adımda gerçekleştirilmiştir. İlk adımda ürün duyusal kalite profilini belirlenmesi amaçlanmış ve bunun için deneyimli 14 panelist kullanılmıştır. Deneyimli panelistler, DLG (Deutsche Landwirtschafts-Gesellschaft) ile Ritthiruangdej ve Suwonsichon (2006)'dan derlenen, 9 (çok iyi) ve 1 (tüketilemez) skalasına göre ölçüm yapan form kullanmıştır. İkinci adımda ise tüketici beğeni testi gerçekleștirilmiştir. Bunun için farklı yaş ve sosyo-ekonomik konuma sahip 80 tüketici teste tabi tutulmuştur. Tüketicilere 1 (hiç beğenmedim) ve 9 (çok beğendim) arasındaki rakamlarını kullanarak, renk, koku, görünüş, tat ve tuzluluk gibi kriterleri değerlendirmeleri talep edilmiştir. Elde edilen sonuçlar, ortalama puan olarak ilgili alanda ifade edilmiştir.

\section{Fiziko-kimyasal Analizler}

Alabalık soslarının renk ölçümü, renk ölçüm cihazı (Minolta) ile gerçekleştirilmiştir. Örneklerin renkleri $\mathrm{L}^{*}$ (parlaklık - matlık), $\mathrm{a}^{*}$ (kırmızılık - yeşillik) ve $\mathrm{b}^{*}$ (sarılık - mavilik) sembolleri ile 1 - 100 sayıları arasında ortalama değerleri olarak tespit edilmiştir (Brimelow ve Groesbeck, 1993).

Sos örneklerinin $\mathrm{pH}$ değerleri, cam $\mathrm{pH}$ probu (Hanna) takılı olan bir $\mathrm{pH}$ metre (Hanna $\mathrm{pH} 211$ ) ile ölçülmüştür (Ludorf ve Meyer, 1973). Soslardaki tuz miktarı ise Mohr metoduna göre tayin edilmiştir (AOAC, 2000).

\section{Besin Kompozisyonu Analizleri}

$\mathrm{Su}$ analizi kurutma yöntemine, protein tayini Kjeldahl metoduna ve kül tayini de yakma metoduna göre yapılmıştır (AOAC, 2000). Yağ analizi ise, Bligh ve Dyer (1959) metoduna göre gerçekleștirilmiş, karbohidrat miktarı ise, besin kompozisyonu bileşenlerinin miktarının 100'den çıkarılması ile kalan miktar olarak belirlenmiştir. 


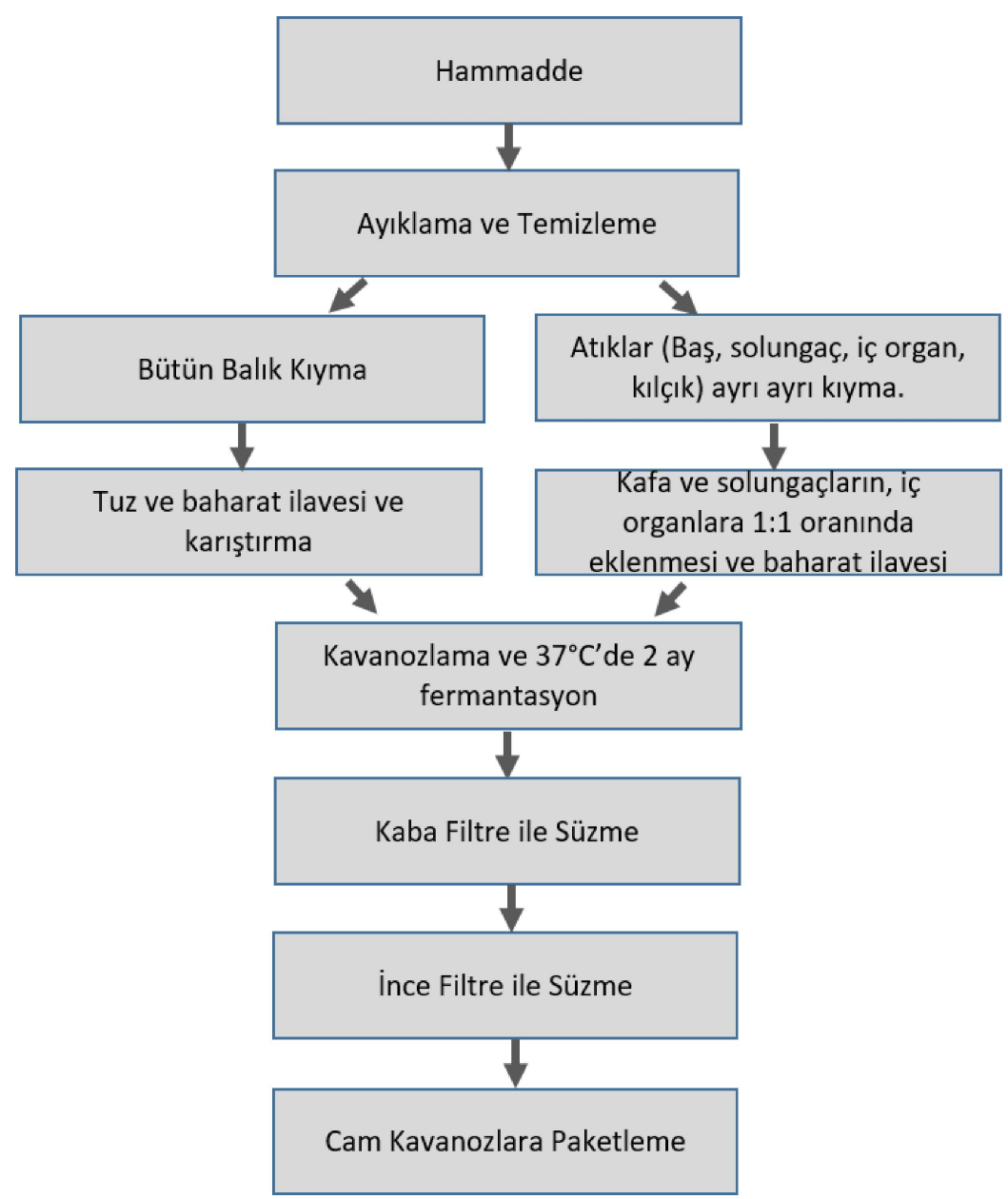

Şekil 1. Bütün alabalık ve alabalık atıklarından balık sosu üretimi işlem akış şeması

\section{Biyojen Amin Analizi}

Sos örneklerindeki biyojen amin miktarı iki aşamada belirlenmiștir. İlk aşamada, örneklerden ekstraksiyon işlemi yapılmıștır. Eerola ve ark. (1993)'ne göre gerçekleștirilen ekstraksiyon işleminde,

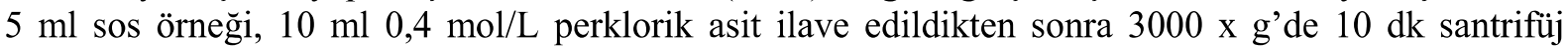
işlemine tabi tutulmuştur. Santrifüj sonrası üstte kalan berrak kısım Whatman 2 filtre kağıdından geçirilmiş ve üzerine $10 \mathrm{ml}$ perklorik asit ilave edilerek $1 \mathrm{dk}$ vortekslenmiş ve tekrar $3000 \mathrm{x}$ g'de 10 dk santrifüj edilmiştir. Santrifüj sonrasında yine berrak kısım alınarak perklorik asit ile 25 ml'ye tamamlanmış ve türevlendirme işlemine geçilmiştir (Eerola ve ark., 1993).

İkinci aşama olan türevlendirme işleminde $0,5 \mathrm{ml}$ ekstrakte edilen sos örneği alınmış ve üzerine sırasıyla $100 \mu \mathrm{l} 2 \mathrm{~N} \mathrm{NaOH}$ çözeltisi, $150 \mu \mathrm{l}$ doymuş sodyum bikarbonat çözeltisi ve $1 \mathrm{ml}$ dansil klorür ilave edilmiștir. Vortekslenen örnekler, $40^{\circ} \mathrm{C}^{\prime} \mathrm{de} 45 \mathrm{dk}$ inkübe edilmiş ve inkübasyon sonrasında $10 \mathrm{dk}$ karanlık ortamda bekletilen örneklerin üzerine $50 \mu 1 \% 25^{\prime}$ lik amonyak eklenmiștir. Tekrar karanlıkta $30 \mathrm{dk}$ inkübe edilen örneklerin üzerine $3,2 \mathrm{ml}$ amonyum asetat+asetonitril ilave edilmiş ve toplam hacim 5 ml'ye tamamlanmıştır. Tekrar vortekslenen örnekler, $0,45 \mu l$ 'lik filtreden geçirilerek, Zorbax Eclipse XDB-C18-5 $5 \mu \mathrm{m}(4,6 \times 150 \mathrm{~mm})$ kolonu bulunan, HPLC cihazına (Shimadzu) enjekte edilmiștir.

Mikrobiyolojik Analizler

Sos örneklerinin, peptonlu su kullanılarak öncelikle desimal seyreltimleri yapılmış ve ekimler, örneğin kendisi ile bu seyreltimlerden yapılmıştır. Analizlerde, toplam aerobik bakteri, toplam halofilik bakteri, Lactobacillus sp. ve Bacillus sp varlığı incelenmiștir (FDA/BAM,1998). Toplam aeobik bakteri sayımı için PCA (Merck), toplam halofilik bakteri sayımında $\% 7 \mathrm{NaCl}$ ilave edilmiş PCA (Merck), Lactobacillus sp. sayımında MRS Agar (Merck) ve Bacillus sp. sayımında MYP Agar (Oxoid) kullanılmıştır. Tüm mikroorganizmaların sayımında yayma plak yöntemi kullanılmış, 
petrilerin inkübasyon süre ve sıcaklıkları ise kullanılan besiyerlerinin üretici talimatlarına göre gerçekleștirilmiştir.

\section{Istatistiki Analizler}

Araştırmada sos grupları analiz sonuçlarındaki farklılıkların tespiti amacıyla "tek yönlü varyans analizi (ANOVA)" uygulanmıştır. Tüm analizler ise üç tekerrürlü olarak gerçekleştirilmiş ve güven aralığı $\mathrm{P}<0,05$ olarak seçilmiştir. Verilerin tek yönlü varyans analizi (ANOVA) için uygunluğu Anderson-Darling (normal dağılım için) ve Levene's eşit varyans (homojen dağılım için) testleri uygulanarak belirlenmiştir. Sos gruplarında tarife dayalı duyusal analiz ve tüketici beğeni testi sonuçlarının karşılaştırılması amacıyla verilere, parametrik olmayan testlerden Kruskal-Wallis analizi uygulanmıştır. İstatistikî analizlerde Minitab 17 ve IBM SPSS Statistics 20 istatistik paket programları kullanılmıştır.

\section{Bulgular ve Tartışma}

$\mathrm{Bu}$ çalışmada, tatlı su kültür balığı olan gökkuşağı alabalığından balık sosu üretimi gerçekleștirilmiş ve elde edilen sos gruplarının duyusal, fiziksel, kimyasal ve mikrobiyolojik açıdan kaliteleri incelenmiştir.

Balık sosu; karakteristik tat ve aroması fermantasyon sirasında otolitik ve bakteriyel enzimlerin protein ve lipidleri parçalaması neticesinde ortaya çıkan, berrak kahverengi sıv1 hidrolizatlardır (Beddows, 1985). Soslarda renk, kalite belirleyici faktör olarak kullanılmaktadır. Balık sosları ile yapılan çalışmalarda, sosun rengi berrak kahverengi olmalıdır. Bu çalışmada alabalık ve atıklarından elde edilen balık sosu da ticari soslara genel yap1 itibariyle benzerlik gösteren, kırmızıkahverengi berrak sıvı bir üründür. Renk özelliklerini ifade eden $L^{*}, a^{*}$ ve $b^{*}$ değerleri bütün balık ve atık sos gruplarında sırasıyla 58-53 (L*), 19 - $18\left(\mathrm{a}^{*}\right)$ ve 53 - $47\left(\mathrm{~b}^{*}\right)$ olarak tespit edilmiştir (Çizelge 1). Tespit edilen bu değerler; örneklerde orta parlaklık, kırmızıya dönük ve sarı ile mavinin aynı oranlarda bulunduğunu ifade etmektedir. Üretimde sosun sahip olduğu kahverenginin yoğunluğu; balık türü, üretim şekli, ilave edilen maddelerin çeşidi, fermantasyon süresi gibi etkenler ile değişebilmektedir. Balık sosu ile ilgili yapılan çalışmalarda, renk değerlerinin genellikle fermantasyon ve depolama sırasında değişim gösterdiği bildirilmiştir. Örneğin, Dissaraphong ve ark. (2006), ton balığı (Kastsuwonus pelamis) iç organlarından ürettiği sosun fermantasyon sürecinde $\mathrm{L}^{*}$ değerinin azalırken $\mathrm{a}^{*}$ ve $\mathrm{b}^{*}$ değerinin ise arttığını rapor etmişlerdir. Bu araştırmacıların son ürünlere ait bildirdiği $\mathrm{L}^{*}$ (40-20), a* (35-30) ve $\mathrm{b}^{*}(60-40)$ değerlerinin çalışmamızda tespit edilen renk değerleri ile benzer olduğu belirlenmiștir. Tuzlanmış ve fermente edilmiş hamsi balığı (Engraulis japonica) ile yapılan başka bir çalışmada ise depolama sırasında renk değerlerinin tümünün azaldığı bildirilmiştir (Kim ve ark., 2004). Aslında soya sosunda olduğu gibi, balık sosunda da rengin oluşmasında katkısı olan en büyük etken fermantasyon esnasinda meydana gelen Maillard reaksiyonu ve melanoidin üretimidir (Lee ve ark., 1997; Lopetcharat ve ark., 2001). Böylelikle, balık soslarında kahve rengin oluşmasi; fermantasyon sırasında söz konusu reaksiyonlarla birlikte $L^{*}$ değerinin düşmesi ve $a^{*}$ değerinin artması sonucunda mümkün olmaktadır (Dissaraphong ve ark., 2006).

Yapılan duyusal analizlerde de sos örnekleri başta renk olmak üzere çeşitli kriterler açısından değerlendirilmiştir. Sosun rengi olan kahverengin bütün alabalık $(6,9)$ ile alabalık atık $(6,7)$ örnekleri arasında bariz bir farklılık içermediği belirlenmiştir. Duyusal özellikler, gıda ürünlerinin kalitesini belirleyen en önemli parametredir. Görünüss, tat, koku ve aroma ya yönelik olarak bu parametrelerin ölçümü çeşitli skalalar kullanılarak panelist veya tüketiciler ile gerçekleştirilmektedir. Bu çalışmada, duyusal analizlere ait tespit edilen bulgular Şekil 2 ve 3 'te özetlenmiştir.

Duyusal testlere katılan panelistler ürün duyusal profilini karakteristik renk olan kahverengi görünüme sahip, fermente karamelize ve balıksı aromalarda ve tuzlu olarak belirlemişlerdir. Tüketici beğeni testinde ise tüketiciler panelistler ile ortak görüş olarak kahverengi ve tuzlu tadı ortak sonuç olarak çıkarmıştır. Bununla birlikle, alabalık atıklarından elde edilen sosların lezzet konusunda bütün alabalık soslarına yakın değerde olduğu ve diğer parametrelerde de eşdeğer özelliklere sahip olduğu görüşünü bildirmişlerdir. Buna göre, bulgular, balık sosu üretiminin, balık atıklarından veya balığın tamamından olmasının büyük bir farklılığa neden olmadığı sonucuna işaret etmektedir $(P<0,05)$. Yapılan diğer çalışmalarda da araştırmacılar, farklı balıkların, farklı kısımlarından üretilen soslarda duyusal olarak bariz bir farklılığın tespit edilemediğini, görülebilen bazı farklılıkların ise özellikle aroma ve lezzet parametrelerinde gerçekleştiğini vurgulamışlardır (Gildberg ve ark., 2007; Jiang ve 
ark., 2007). Farklılıkların oluşmasındaki en önemli etkenin ise, hammaddenin farklılı̆̆ından ziyade, fermantasyon şartları ve süresi olarak ifade edilmiştir (Jiang ve ark., 2007). Araştırmacıların duyusal testler için bildirdiği bu görüş ve raporların çalışmamızla örtüştüğü belirlenmiştir.

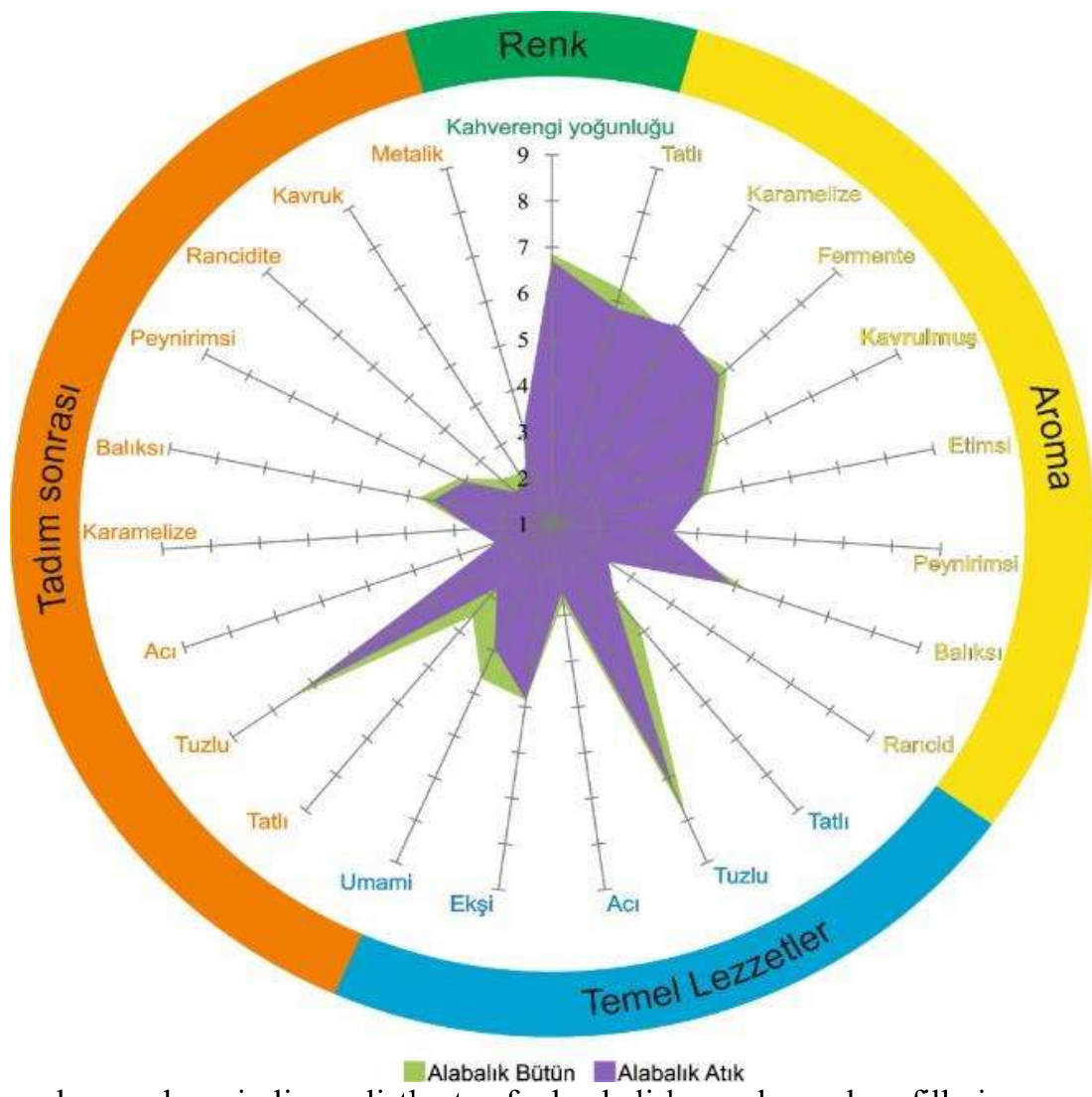

Şekil 2. Alabalık soslarının deneyimli panelistler tarafindan belirlenen duyusal profilleri

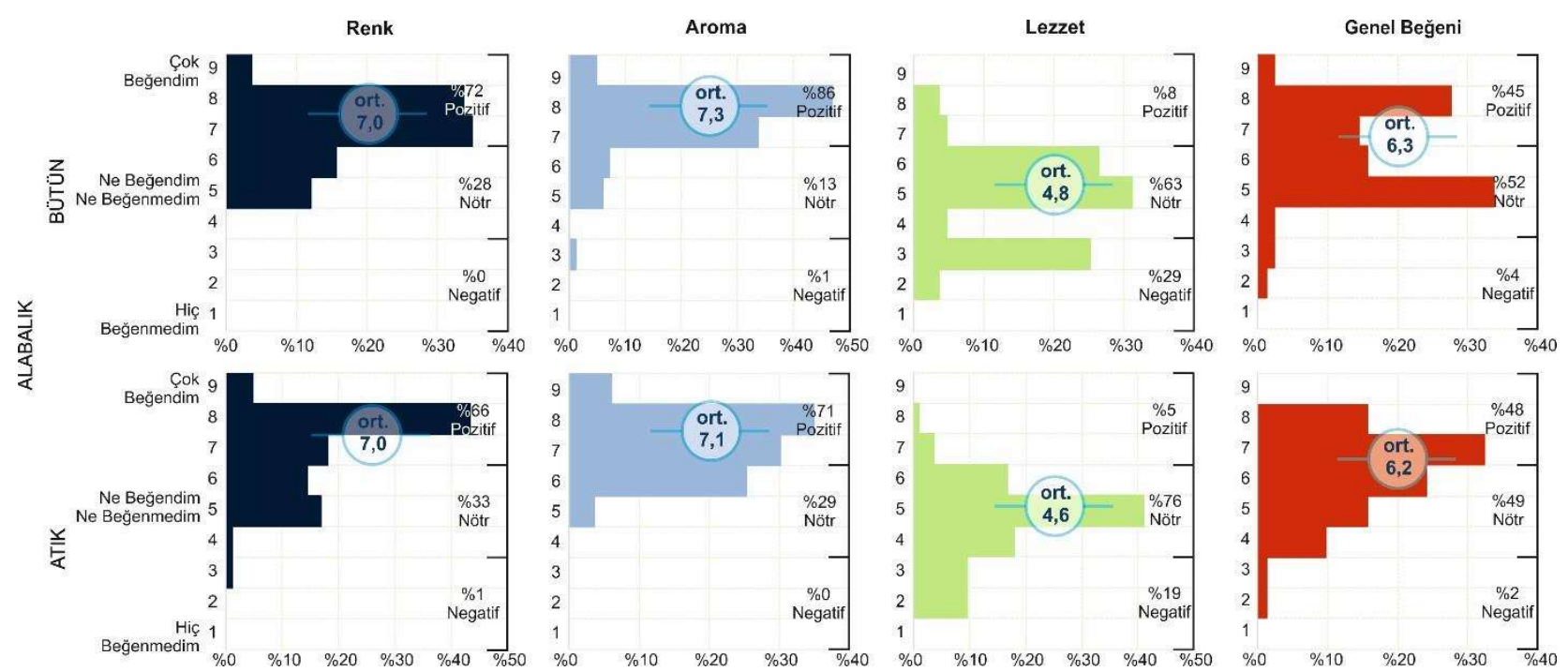

Şekil 3. Alabalık soslarının tüketici beğeni testi sonuçları

Gıdalarda $\mathrm{pH}$ değeri, mikrobiyal ve enzimatik aktiviteyi etkilemesinden dolayı önemli bir parametredir. $\mathrm{Bu}$ çalışmada alabalık soslarının 5,77 ve $5,33 \mathrm{pH}$ değerlerine sahip olduğu tespit edilmiştir. Tespit edilen bu değerlerin ise; Ibrahim (2010) ve Cho ve ark. (1999) ve Ijong ve Ohta (1995)'nın bildirdiği değerlerden daha düşük, ancak, Cho ve ark. (2000) ve Aquerreta ve ark. (2001)'nin bildirdiği değerler ile uyumlu olduğu gözlemlenmiştir. Balık soslarının pH'larındaki 
farklılıklar, fermantasyon süresince bakteriyel aktiviteyi yansıtmaktadır. Dolayısıyla, hammadde farklılığı, fermantasyon süresi ve sıcaklığı, kullanılan baharat ve tuzun miktarları bu aktiviteyi doğrudan veya dolaylı olarak etkilemektedir.

Tuz miktarı, balık soslarında genellikle yüksek seviyelerde bulunmaktadır. Tuzun hem koruyucu hem de olgunlaştırıcı etkisi, fermantasyon süresince faydalanılan özelliklerdir. Alabalık soslarındaki tuz miktarları \%18 civarında belirlenmiștir, bu tuz seviyesi ticari ve deneysel olarak üretilen soslarının tuz miktarlarına benzer durumdadır. Genellikle balık sosları \%10-18 civarında tuz ihtiva etmekte, ancak deneysel olarak üretilen bazı balık soslarında bu oran $\% 10$ altına düşebilmektedir (Ibrahim, 2010).

Çizelge 1. Alabalık soslarında bazı fiziko-kimyasal özelliklere ait tespit edilen değerler

\begin{tabular}{lrr}
\hline Fiziko-kimyasal özellikler & Bütün & Atık \\
\hline$L^{*}$ değeri & $58,65 \pm 0,51^{\mathrm{a}}$ & $53,82 \pm 1,14^{\mathrm{b}}$ \\
$a^{*}$ değeri & $19,15 \pm 0,90^{\mathrm{a}}$ & $18,38 \pm 1,81^{\mathrm{a}}$ \\
$b^{*}$ değeri & $53,41 \pm 0,33^{\mathrm{a}}$ & $47,78 \pm 1,97^{\mathrm{b}}$ \\
$\mathrm{pH}$ & $5,77 \pm 0,02^{\mathrm{a}}$ & $5,53 \pm 0,01^{\mathrm{b}}$ \\
Tuzluluk & $17,42 \pm 0,21^{\mathrm{a}}$ & $18,25 \pm 0,09^{\mathrm{b}}$ \\
\hline
\end{tabular}

Aritmetik ortalama \pm Standart sapma, Örnek sayısı; $\mathrm{N}=3$.

Aynı satırdaki farklı harfler $(\mathrm{a}, \mathrm{b})$ gruplar arasındaki farkı belirtir $(\mathrm{P}<0,05)$

Alabalık soslarının besleyici özelliklerinin belirlenmesi amacıyla besin kompozisyonu analizleri yapılmış, elde edilen bulgular Çizelge 2'de özetlenmiştir. Alabalık soslarında tespit edilen su miktarı \% 59-60 civarında iken, protein miktarları \% 10-13 aralığında belirlenmiştir. Sosların yă miktarının \% 5-6 aralığında sınırlı kaldığı tespit edilmiş ancak, kül miktarının \% 19-20 oranında çıktığ 1 belirlenmiştir.

Çizelge 2. Alabalık soslarına ait besin kompozisyonu analizi bulguları (\%)

\begin{tabular}{lrr}
\hline Besin bileşenleri & Bütün & Atık \\
\hline Su & $59,79 \pm 0,65^{\mathrm{b}}$ & $61,71 \pm 0,42^{\mathrm{a}}$ \\
Protein & $13,02 \pm 0,45^{\mathrm{a}}$ & $10,55 \pm 0,62^{\mathrm{b}}$ \\
Yağ & $5,21 \pm 0,13^{\mathrm{b}}$ & $6,07 \pm 0,22^{\mathrm{a}}$ \\
Kül & $19,34 \pm 0,25^{\mathrm{b}}$ & $20,30 \pm 0,14^{\mathrm{a}}$ \\
Karbohidrat & $2,64 \pm 0,09^{\mathrm{a}}$ & $1,38 \pm 0,08^{\mathrm{a}}$ \\
\hline
\end{tabular}

Aritmetik ortalama \pm Standart sapma, Örnek sayıs1; $\mathrm{N}=3$.

Aynı satırdaki farklı harfler $(a, b)$ gruplar arasındaki farkı belirtir $(\mathrm{P}<0,05)$.

Karbohidrat miktarının ise \% 1-3 arasında olduğu belirlenmiştir (Çizelge 2). Tespit edilen değerler incelendiğinde, bütün balığın sos olarak işlenmesinde kaybın genel olarak sadece su miktarında olduğu anlaşılmaktadır. Genellikle taze alabalık, \% 73-80 su, \% 15-19 protein, \% 3-6 yă ve \% 1-2 kül içermekte, karbohidrat ise çok düşük miktarlarda olduğundan göz ardı edilmektedir (Ünlüsayın ve ark., 2001; Akhtar, 1994). Alabalık soslarında tespit edilen değerler incelendiğinde ise; su miktarındaki azalma ve kül miktarındaki artış bariz bir durumda iken, protein ve yağ içeriğindeki değişim ise daha makul düzeyde kalmıștır. Diğer taraftan, atıklardan elde edilen sos ise neredeyse bütün balık kadar protein (\% 10) ve yağ (\% 6) içeriğine sahip olduğu görülmektedir. Bu durum aynı zamanda atık veya bütün balığın sos olarak işlendiğinde besleyiciliği açısından çok büyük farklılara sahip olmadığını da göstermektedir. Yapılan diğer çalışmalarda balık soslarında tespit edilen besin kompozisyonu bulguları arasında büyük farklılıklara rastlanabilmektedir. Genel anlamda balık soslarının besin kompozisyonlarının \% 60-85 su, \% 8-13 protein, \% 1-3 yağ ve \% 18-20 kül miktarına sahip olduğu rapor edilmektedir (Cho ve ark., 2000; Gildberg ve ark., 2007; Ibrahim, 2010). Araştırıcıların bildirdiği bu değerler ile bu çalışmada tespit edilen alabalık sosu değerleri benzerlik göstermektedir. Az miktarda görülen farklıların ise, hammadde ve fermantasyon işlemindeki farklılıklardan kaynaklandığı düşünülmektedir.

Biyojen aminler, serbest amino asitlerin, dekarboksilaz enziminin etkisi ile dekarboksilasyona uğraması ile oluşmaktadır. Biyojen aminler, taze balıklarda olabileceği gibi, bayat ve kokuşmuş 
balıklarda artan miktarlarda olabilmektedir. Bu çalışma da fermantasyon işlemi sırasında oluşabilecek 8 biyojen aminin miktarı tespit edilmeye çalışılmış, elde edilen bulgular Çizelge 3 'te özetlenmiştir.

Çizelge 3. Alabalık soslarının biyojen amin seviyeleri

\begin{tabular}{lrr}
\hline Biyojen aminler & Bütün & Atık \\
\hline Triptamin & TE & TE \\
Betafeniletilamin & TE & TE \\
Putresin & $16.65 \pm 0.35^{\mathrm{b}}$ & $26.27 \pm 0.18^{\mathrm{a}}$ \\
Kadaverin & $15.71 \pm 2.48^{\mathrm{a}}$ & $10.24 \pm 0.95^{\mathrm{b}}$ \\
Histamin & $\mathrm{TE}$ & $\mathrm{TE}$ \\
Tiramin & $12.62 \pm 0.08^{\mathrm{b}}$ & $25.36 \pm 0.09^{\mathrm{a}}$ \\
Spermidin & $\mathrm{TE}$ & $\mathrm{TE}$ \\
Spermin & $\mathrm{TE}$ & $\mathrm{TE}$ \\
Toplam & 44.98 & 61.87 \\
\hline Aritmetik ortalama \pm Standart sapma, Örnek sayısi; N=3, TE: Tespit edilemedi. & \\
Aynı satırdaki farklı harfler $(\mathrm{a}, \mathrm{b})$ gruplar arasindaki fark belirtir $(\mathrm{P}<0,05)$. &
\end{tabular}

Örneklerde, putresin, kadaverin ve tiramin biyojen aminleri tespit edilebilmiş ve değerlerinin 10,24- $26,27 \mathrm{mg} / \mathrm{kg}$ arasında olduğu belirlenmiştir $(\mathrm{P}<0,05)$. Fermantasyona tabii tutulan balık sosunun biyojen amin içeriği, taze balık etine göre daha yüksek oranlarda olabilmektedir (Stute ve ark., 2002). Ancak yapılan bu çalışmada, alabalık soslarındaki tespit edilebilen putresin kadaverin ve tiramin biyojen aminlerinin düşük seviyelerde olduğu belirlenmiştir. Genellikle, balık ve balık ürünlerinde, biyojen aminler arasından histamin, risk teșkil eden amin olduğundan kontrolü yapılmaktadır (Stute ve ark., 2002). Bu çalışmadaki alabalık soslarında, histamin tespit edilmemiş, diğer biyojen aminlerin ise düşük miktarlarda olduğu belirlenmiştir. $\mathrm{Bu}$ durumun, sos yapımında kullanılan yüksek tuz miktarı ile çeşitli baharatların, biyojen amin oluşturan mikroorganizmaların gelişimini baskılayıcı özelliklerinden kaynaklandığı düşünülmektedir (Ten Brink ve ark., 1990; Shalaby, 1996; Silla Santos, 1996).

Çizelge 4. Alabalık soslarında tespit edilen mikroorganizma sayıları (kob/ml*)

\begin{tabular}{lll}
\hline Mikroorganizma & Bütün & Attk \\
\hline TAB & $1,1 \times 10^{1}$ & $1,2 \times 10^{1}$ \\
HB & $<10^{1}$ & $<10^{1}$ \\
Lac. & $<10^{1}$ & $<10^{1}$ \\
Bac. & $<10^{1}$ & $<10^{1}$ \\
\hline
\end{tabular}

*kob: koloni oluşturan birim TAB: Toplam mezofilik aerobik bakteri, HB: halofilik bakteri, Bac.: Bacillus sp., Lac.:

Lactobacillus sp., Örnek sayıs1; $\mathrm{N}=3$.

Fermente ürün olan balık soslarında, kullanılan yüksek tuz konsantrasyonu nedeniyle mikroorganizmalar üzerinde güçlü inhibisyon etkisi yaratılmaktadır. Bu çalışmada, alabalık soslarının mikrobiyolojik yapısı hakkında bilgi edinebilmek amaciyla, toplam aerobik bakteri, toplam halofilik bakteri, Lactobacillus sp. ve Bacillus sp. bakterilerinin sayımı yapılmıştır. Çizelge 4'te özetlenen bulgulara göre, alabalık soslarının mikroorganizma sayıları her iki grupta da $10^{1} \mathrm{kob} / \mathrm{g}$ civarında tespit edilmiştir. Bunun anlamı, sos üretiminde kullanılan tuz ve baharatların etkisiyle balık hamurlarında bulunan mikroorganizmaların, fermantasyon süresince öldüğü ve son üründe çok az miktarda $\left(10^{1}\right.$ $\mathrm{kob} / \mathrm{g}$ ) mikroorganizmanın canlı kalabildiğidir. Bu çalışmada tespit edilen düşük mikroorganizma içeriğinin, daha önceki çalışmalarda bildirilen değerlerle uyum içerisinde olduğu belirlenmiştir (Lopetcharat ve Park, 2002; Dissaraphong ve ark., 2006).

\section{Sonuç}

Balık sosu, kendisiyle aynı sınıf olan diğer sos ürünlerine göre daha besleyici ve üretimi kolay olan bir üründür. Yapıldığı hammaddenin karakteristik özelliklerini taşıyan balık sosu, ekonomik olarak da katma değeri yüksek bir gıda ürünüdür. Protein kaynaklarının her çeşidinin değerli ürünlere dönüştürülmesi, bir taraftan ihtiyaç olan protein açığının kapatılması, diğer taraftan ise ülke ekonomisine yüksek değerde ürünlerle geri dönüşümün sağlanması açısından önemlidir. Dolayısıyla ülkemizin de, sahip olduğu her kaynağını etkin şekilde kullanımı ve katma değeri yüksek ürünlerin 
düşük maliyetle üretilmesi elzem durumdadır. Bu çalışma ile balık atıklarının, aslında bütün balık kadar değerli ürünlere dönüşebileceği, üretilen balık soslarının karakterizasyonu yapılarak ifade edilmeye çalışılmış, elde edilen bu bulguların sektöre katkı sağlayabileceği düşünülerek sunulmuştur.

Teşekkür: Bu çalışma, Çanakkale Onsekiz Mart Üniversitesi, Bilimsel Araştırma Projeleri Destekleme Biriminin FYL-2014-157 kodlu projesi ile desteklenmiştir.

\section{Kaynaklar}

Akhtar, N., 1994. Fish composition and balance in population in Rawal Dam reservoir of Pakistan. Pakistan Journal of Zoology. 61: 111-118.

Alasalvar, C., Shahidi, F., Quantick, P., 2002. Food and health applications of marine nutraceuticals: A review. In Seafoods - Quality, Technology and Nutraceutical Applications. ed: Alasalvar C., Taylor T. Springer Berlin Heidelberg pp. 175-204 Heidelberg, Berlin.

AOAC, 2000. Official methods of analysis of the AOAC international (17th). Horwitz W. Association of Official Analytical Chemists. 2000 p. Washington DC, USA.

Aquerreta, Y., Astiasaran, I., Bello, J. 2001. Use of exogenous enzymes to eloborate the Roman fish sauce garum. Journal of the Science of Food and Agriculture. 82: 107-112.

Atılgan, E., 2008. Ülkemizde su ürünleri işleme sanayinin ürün çeşidine göre üretim miktarları ve işleme atıklarının değerlendirilmesi üzerine bir araştırma. Van Yüzüncü Yıl Üniversitesi Fen Bilimleri Enstitüsü, Su Ürünleri Anabilim Dalı, Yüksek Lisans Tezi. $62 \mathrm{~s}$.

Beddows, C.G., Ardeshir, A.G., Daud, W.J.B., 1979. Biochemical changes occurring during the manufacture of budu. Journal of the Science of Food and Agriculture. 30: 1097-1103.

Bligh, E.G., Dyer, W.J., 1959. A Rapid method of total lipid extraction and purification. Canadian Journal of Biochemistry and Physiology. 37: 911-917.

Brimelow, C.J.B., Groesbeck, C.A. 1993. Colour measurement of foods by colour reflectance instrumentation. In: E. Kress-Rogers (ed.). Instrumentation and Sensors for the Food Industry. Woodhead Publishing pp. 63-79 Cambridge, UK.

Cho, Y.J., Im, Y.S., Lee, K.W., Kim G.B., Choi, Y.J., 1999. Changes of components in salt-fermented northern sand lance, Ammodytes personatus sauce during fermentation. J. of the Korean Fisheries Society. 32: 693-698.

Cho,Y.J., Im, Y.S., Park, H.Y., Choi, Y.J., 2000. Quality Characteristics of Southeast Asian salt-fermented fish sauces. Journal of the Korean Fisheries Society. 32: 693-698.

Dissaraphong, S., Benjakul, S., Visessanguan, W., Kishimura, H., 2006. The influence of storage conditions of tuna viscera before fermentation on the chemical, physical and microbiological changes in fish sauce during fermentation. Bioresource Technology. 97: 2032-2040.

Eerola, S., Hinkkanen, R., Lindfors, E., Hirvi, T., 1993. Liquid-chromatographic determination of biogenic amines in dry sausages. Journal of AOAC International. 76: 575-577.

FDA/BAM, 1998. Bacteriological analytical manual edition 8. Revision A. Food and Drug Administration (FDA) Division of Microbiology and Association of Official Analytical Chemists. 250 p. New Hampshire, USA.

Gao, M.T., Hirata, M., Toorisaka, E., Hano, T., 2006. Acid-hydrolysis of fish wastes for lactic acid fermentation. Bioresource Technology. 97: 2414-2420.

García, A.J., Esteban, M.B., Márquez, M.C., Ramos, P., 2005. Biodegradable municipal solid waste: Characterization and potential use as animal feedstuffs. Waste Management. 25: 780-787.

Gildberg, A., 2001. Utilisation of male Arctic capelin and Atlantic cod intestines for fish sauce production evaluation of fermentation conditions. Bioresource Technology. 76: 119- 123.

Gildberg, A., Wichaphon, J., Lertsiri, S., Assavanig, A., Sørensen, N.K., Thongthai, C., 2007. Chemical and organoleptic comparison of fish sauce made from cold water species and typical Thai fish sauce. Journal of Aquatic Food Product Technology. 16: 31-42.

Gülyavuz, H., Ünlüsayın, M., 2008. Su Ürünleri İșleme Teknolojisi. Akdeniz Üniversitesi Su Ürünleri Fak. Ders Kitabi. Antalya.

Ibrahim, S.M., 2010. Utilization of gambusia (Affinis affinis) for fish sauce production. Turkish Journal of Fisheries and Aquatic Sciences. 10:169-172.

ICMSF, 1986. Microorganisms in foods. 2, sampling for microbiological analysis: principles and specific applications, Societies I.C.o.M.S.f.F.I.o.t.I.U.o.M. Ed. Blackwell Scientific Publications 293 p. Oxford.

Ijong, F.G., Ohta, Y., 1995. Amino acid composition of bakasang, a traditional fermented fish sauce from Indonesia. Lebensm. Wiss. U.-Technol. 28: 236-237.

Jiang, J.J., Zeng, Q.X., Zhu, Z.W., Zhang, L.Y., 2007. Chemical and sensory changes associated Yu-lu fermentation process - A traditional Chinese fish sauce. Food Chemistry. 104: 1629-1634. 
Kim, J.H., Ahn, H.J., Yook, H.S., Kim, K.S., Rhee, M.S., Ryu, G.H., Byun, M.W., 2004. Color, flavor, and sensory characteristics of gamma-irradiated salted and fermented anchovy sauce. Radiation Physics and Chemistry. 69: 179-187.

Lee, Y.S., Homma, S., Aida, K., 1997. Characterization of melanoidin in soy sauce and fish sauce by electrofocusing and high performance gel permeation chromatography. Nippon Shokuhin Kogyo Gakkaishi. 34: 313-319.

Lopetcharat, K., Choi, Y.J., Park, J.W., Daeschel, M.A., 2001. Fish Sauce Products and Manufacturing: A Review. Food Reviews International. 17: 65-88.

Lopetcharat, K., Park, J.W., 2002. Characteristics of fish sauce made from pacific whiting and surimi byproducts during fermentation stage. Journal of Food Science. 67: 511-516.

Ludorf, M., Meyer, W., 1973. Fische und Fischerzeugnisse. Paul Parey Verlag pp. 309. Hamburg-Berlin.

Stefansson, G., Steingrimsdottir, U., 1990. Application of enzymes for fish processing in Iceland present and future aspects, In Advances in fisheries technology and biotechnology for increased profitability. ed: Voigt M.N., Botta J.R., Technomic Publishing CO pp. 237-250 Lancaster, PA.

Ostermeyer, U., Meyer, C., Schubring, R., 2009. Herstellung und Zusammensetzung von asiatischen Fischsaucen-Production and composition of Asian fish sauces. Informationen aus der Fischereiforschung. 56: 1-18.

Ritthiruangdej, P., Suwonsichon, T., 2006. Sensory properties of Thai fish sauces and their categorization. Kasetsart Journal - Natural Science. 40: 181-191.

Stute, R., Petridis, K., Steinhart, H., Biernoth, G., 2002. Biogenic amines in fish and soy sauces. European Food Research Technology. 215: 101-107.

Shahidi, F., 2002. Marine nutraceuticals, Inform - International News On Fats, Oils and Related Materials. 13: 57.

Shalaby, A.R., 1996. Significance of Biogenic Amines to Food Safety and Human Health, Food Research International. 29: 675-690.

Silla Santos, M.H., 1996. Biogenic amines: Their importance in foods. International Journal of Food Microbiology. 29: 213-231.

Ten Brink, B., Damink, C., Joosten, H.M.L.J., Huis IN 'T VELD, J.H.J., 1990. Occurrence and formation of biologically-active amines in foods. International Journal of Food Microbiology. 11: 73-84.

Unlusayin, M., Kaleli, S., Gulyavuz, H., 2001. The determination of flesh productivity and protein components of some fish species after hot smoking. Journal of the Science of Food and Agriculture. 81: 661-664. 